\title{
PENDAMPINGAN BAGI MASYARAKAT KURANG MAMPU DI KABUPATEN LOMBOK TIMUR DI MASA PANDEMI
}

\author{
Siti Nurul Hijah ${ }^{1 *)}$, Syakirin ${ }^{2)}$ \\ ${ }^{1,2)}$ Fakultas Teknik Program Studi Teknik Sipil Universitas Islam Al-Azhar \\ e-mail :nurulhijah.nh@gmail.com
}

\begin{abstract}
Abstrak
Kabupaten Lombok Timur yang menjadi lokasi pendampingan dimasa pendemi Covid-19 di beberapa desa yaitu desa Pemongkong, desa Ijobalit dan desa Aikdewa merupakan desa yang terletak di Kabupaten Lombok Timur dengan potensi masyarakat kurang sejahtera dimana kondisi ekonomi sosial sebagian besar masyarakat tidak mampu menyediakan kebutuhan pokok dengan layak. Dampak Pandemi Covid-19 telah membawa perubahan terutama dalam upaya untuk menghambat penyebaran virus covid-19 yang juga menghambat kegiatan perekonomian dan berakibat terhadap tingkat kesejahteraan sosial masyarakat yang menunjukkan tingkat kemiskinan kembali meningkat setelah pandemi Covid-19. Dampak negatif ini terhadap keadaan sosial ekonomi akibat dari pandemi bisa menjadi jauh lebih buruk tanpa adanya bantuan sosial baik dari pemerintah ataupun swasta.

Penulis bekerjasama dengan Vlok Foundation Holland melakukan kegiatan pengabdian kepada masyarakat menggunakan metode sosialisasi dan pemberian bantuan untuk memberikan sumbangsih berupa pembagian masker kain, hand sanitizer, tempat cuci tangan, multivitamin serta bahan pokok makanan kepada masyarakat desa tersebut dengan tujuan dapat membantu meringankan kebutuhan masyarakat dan memotivasi masyarakat untuk menerapkan protokol kesehatan dengan selalu mencuci tangan dan menggunakan masker jika beraktivitas di tempattempat umum agar terhindar dari penularan COVID-19, serta meningkatkan imunitas tubuh dengan mengkonsumsi makanan bergizi.
\end{abstract}

Kata Kunci : Lombok Tmur, Pendampingan, Pandemi

\section{PENDAHULUAN}

Hadirnya pandemi Covid-19 telah membawa perubahan dengan berbagai tantangan yang tidak pernah terbayangkan sebelumnya, dengan membawa dampak sosial-ekonomi yang besar diluar sektor Kesehatan. Dampaknya multisektoral dan efeknya akan terlihat dalam jangka waktu panjang menghantam paling keras masyarakat miskin dan rentan. Saat ini cakupan kerugian yang ditimbulkan sulit untuk diantisipasi sepenuhnya. Sementara pemerintah tengah berupaya meredam dampaknya, terutama yang miskin dan paling rentan, akan terkena dampak parah dari pandemi ini.
Dampak ekonomi tidak hanya dirasakan oleh masyarakat di kota tetapi juga dirasakan oleh masyarakat miskin di pedesaan. Berbagai upaya telah dilakukan pemerintah dalam menghadapi krisis ekonomi ini dengan membantu perekonomian masyarakat yang terdampak Covid-19. Upaya perbaikan dalam memperkuat berbagai program perlindungan sosial untuk menangani krisis setelah pandemi COVID-19 ini telah diperluas untuk melindungi masyarakat miskin terhadap guncangan ekonomi, dan juga masyarakat berpenghasilan menengah kebawah yang jumlahnya terus meningkat namun menjadi rentan terhadap risiko jatuh miskin di kemudian hari. Selain itu, usaha-usaha kecil 
juga menerima bantuan pemerintah seiring dengan upaya mereka untuk terus bertahan di tengah penurunan perekonomian dan pembatasan kegiatan masyarakat setelah pandemi COVID-19. Selain pemerintah pusat dan pemerintah daerah, perguruan tinggi juga turut membantu meringankan beban masyarakat dengan melakukan pendampingan bagi masyarakat kurang mampu.

Mengatasi apa yang terjadi khususnya di Kabupaten Lombok Timur adalah salah satu Kabupaten diantara sepuluh Kabupaten / Kota yang ada di provinsi Nusa Tenggara Barat. Secara administrasi Kabupaten Lombok Timur terdiri dari 21 Kecamatan, 239 Desa, 15 Kelurahan, 1266 Dusun/Lingkungan dengan luas wilayah $2.679,88 \mathrm{Km}^{2}$ serta penduduk kabupaten Lombok Timur 1.325.200 jiwa, merupakan kabupaten dengan jumlah penduduk terbanyak di provinsi NTB, yang menjadi lokasi pendampingan dimasa pandemi Covid19 di beberapa desa yaitu desa Pemongkong, desa Ijobalit dan desa Aikdewa merupakan desa dengan potensi masyarakat kurang sejahtera dimana kondisi ekonomi sosial sebagian besar masyarakat tidak mampu menyediakan kebutuhan pokok dengan layak. Dampak Pandemi Covid-19 telah membawa perubahan terutama dalam upaya untuk menghambat penyebaran virus covid-19 yang juga menghambat kegiatan perekonomian dan berakibat terhadap tingkat kesejahteraan sosial masyarakat yang menunjukkan tingkat kemiskinan kembali meningkat setelah pandemi Covid-19. Dampak negatif ini terhadap keadaan sosial ekonomi akibat dari pandemi bisa menjadi jauh lebih buruk tanpa adanya bantuan sosial baik dari pemerintah ataupun swasta.

Berdasarkan hal tersebut, melihat kondisi masyarakat yang membutuhkan bantuan maka penulis bekerjasama dengan Vlok Foundation Holland melakukan kegiatan pengabdian kepada masyarakat untuk memberikan sumbangsih dan pendampingan kepada masyarakat kurang mampu di desa Pemongkong, desa Ijobalit dan desa Aikdewa. Dengan tujuan untuk memberikan bantuan secara langsung kepada masyarakat berupa pembagian masker kain, hand sanitizer, tempat cuci tangan, multivitamin serta bahan pokok makanan kepada masyarakat desa tersebut agar kami dapat membantu meringankan kebutuhan masyarakat dan memotivasi masyarakat untuk menerapkan protokol kesehatan dengan selalu mencuci tangan dan menggunakan masker jika beraktivitas di tempat-tempat umum agar terhindar dari penularan COVID-19, serta meningkatkan imunitas tubuh dengan mengkonsumsi makanan bergizi.

\section{METODE PELAKSANAAN}

Langkah-langkah sistematis yang dilakukan pada kegiatan pengabdian kepada masyarakat dalam melakukan pendampingan bagi masyarakat kurang mampu adalah sebagai berikut :

Tahap pertama peninjauan lapangan : melakukan survey lokasi dan analisis situasi masyarakat untuk mengetahui kondisi masyarakat dan menentukan jumlah sasaran penerima bantuan. Pengumpulan data melalui wawancara langsung kepada perangkat desa dan beberapa warga kurang mampu didesa tersebut.

Tahap kedua pengolahan data yang telah terkumpul untuk dapat menginvetarisir berapa jumlah bantuan secara langsung diberikan ke masyarakat berdasarkan kriteria yang sudah ditetapkan

Tahap ketiga memberikan arahan, bimbingan, sosialisasi dan distribusi bantuan secara langsung kepada masyarakat. Penyaluran bantuan diawali dengan sosialisasi tentang program-program pemerintah bagaimana penerapan protokol kesehatan dalam mencegah penularan covid19, khususnya tentang penggunaan masker dan cara mencuci tangan yang baik dan benar serta bagaimana pola hidup sehat. Hal ini dilakukan bersama tim perangkat desa dan tim pengabdian kepada masyarakat, kemudian dilanjutkan dengan pembagian bantuan secara langsung kepada masyarakat kurang mampu di Desa Pemongkong, Desa Ijobalit dan Desa Aikdewa. 


\section{HASIL DAN PEMBAHASAN}

Kegiatan pendampingan bagi masyarakat kurang mampu untuk membantu meringankan beban masyarakat di tengah pandemi covid-19 dan mendorong masyarakat untuk berjuang bersama-sama melawan covid-19, sehingga penulis bekerjasama dengan Vlok Foundation Holland melakukan kegiatan pengabdian kepada masyarakat di Desa Pemongkong, Desa Ijobalit dan Desa Aikdewa dengan melakukan beberapa kegiatan sebagai berikut

1. Sosialisasi secara langsung untuk memotivasi masyarakat dalam menerapkan protokol kesehatan dengan selalu mencuci tangan, menjaga jarak dan menggunakan masker jika beraktivitas di tempattempat umum agar terhindar dari penularan Covid-19, serta sosialisasi secara tidak langsung dengan cara memasang poster protokol Kesehatan

2. Pemberian bantuan secara langsung untuk memberikan sumbangsih berupa alat pengukur suhu (Thermogun), pemberian masker kain, hand sanitizer, tempat cuci tangan, multivitamin serta bahan pokok makanan kepada beberapa masyarakat kurang mampu yang ada di Desa Pemongkong, Desa Ijobalit dan Desa Aikdewa. Pemberian bantuan secara langsung ini bertujuan untuk membantu meringankan kebutuhan masyarakat yang diakibatkan oleh lonjakan harga barang dan bahan makanan.

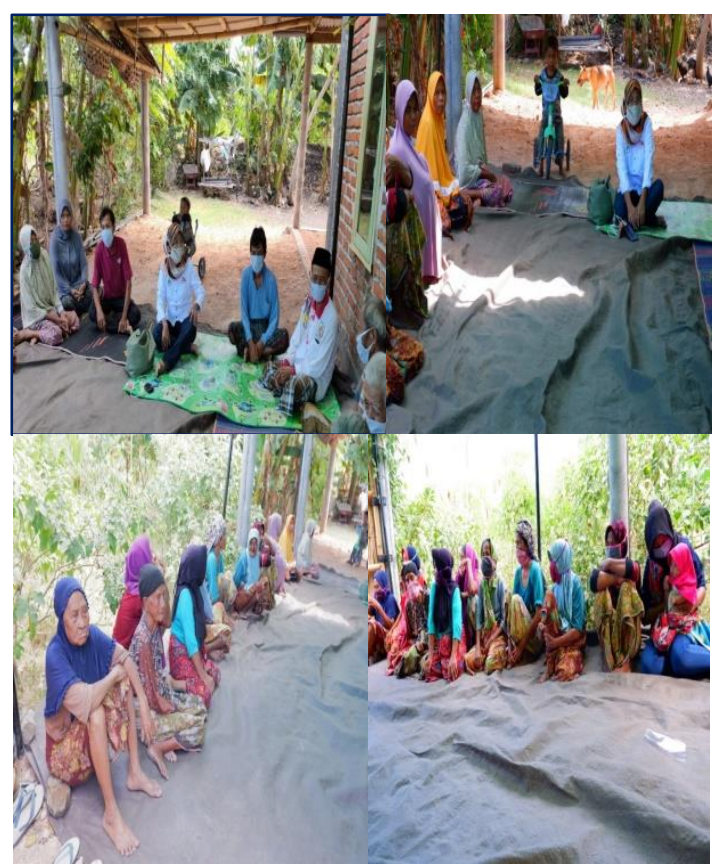

Gambar 1. Kegiatan Sosialisasi di Desa Pemongkong

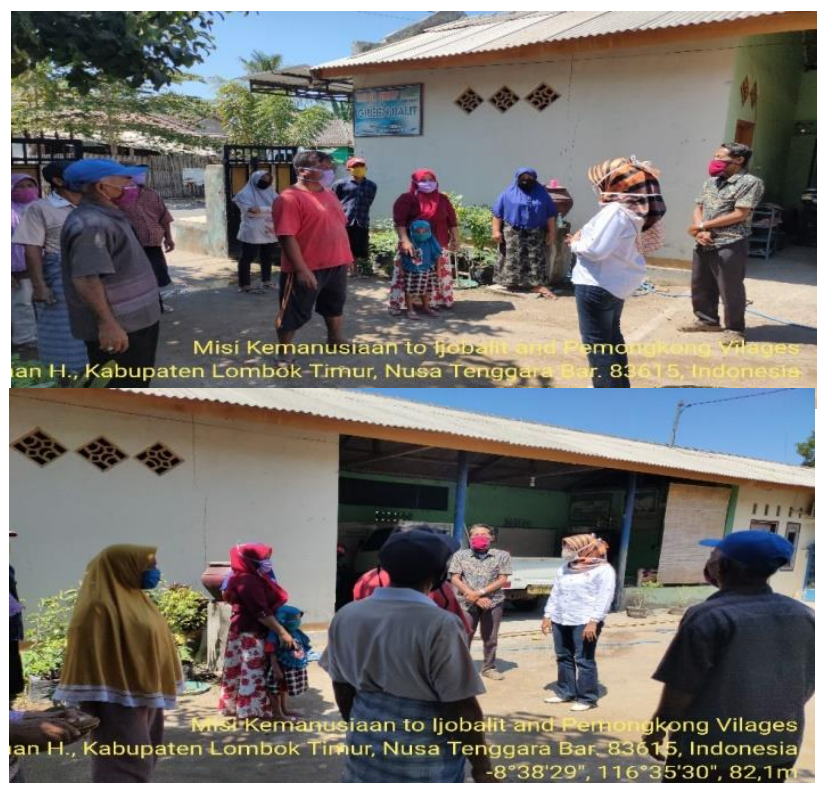

Gambar 2. Kegiatan Sosialisasi di Desa Ijobalit 


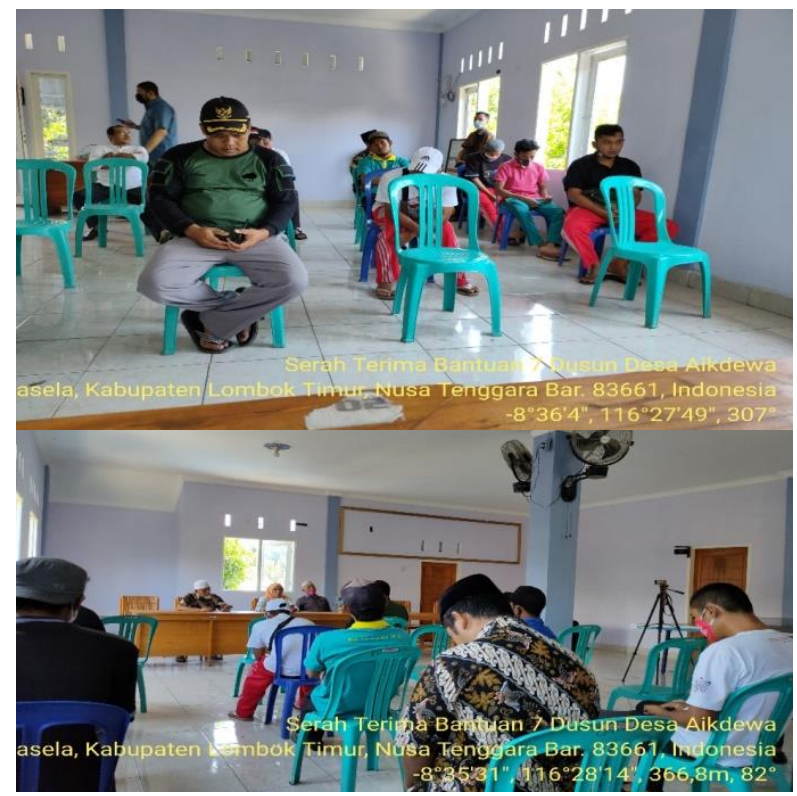

Gambar 3. Kegiatan Sosialisasi di Desa Aikdewa

Pada kegiatan sosialisasi kepada masyarakat, penulis melakukan koordinasi dan sosialisasi dengan pihak sasaran di tiga desa di kabupaten Lombok Timur. Kegiatan ini dilakukan bersama perangkat desa dari tiga desa tersebut. Hal ini bertujuan untuk menentukan masyarakat yang akan menerima bantuan, terutama masyarakat yang belum tersentuh bantuan pemerintah atau masyarakat yang benar-benar membutuhkan bantuan walaupun sudah menerima bantuan dari pemerintah. Adapun kriteria masyarakat yang menerima bantuan adalah keluarga kurang mampu yang tidak menerima bantuan dari pemerintah pusat atau pemerintah daerah, keluarga kurang mampu yang sudah menerima bantuan dari pemerintah tetapi kurang mencukupi, buruh harian yang mengalami penurunan pendapatan selama pandemi covid-19 dan orang tua manula yang hidup sebatang kara dan kurang mampu.

Kegiatan sosialisasi pencegahan penularan covid-19 dan penerapan protokol kesehatan kepada masyarakat yang ada di tiga desa dilakukan oleh tim pengabdian kepada masyarakat dan petugas dari desa. Melalui kegiatan sosialisasi diharapkan masyarakat sadar akan pentingnya menggunakan masker, selalu mencuci tangan dan menjaga jarak serta tidak menganggap remeh covid-19. Untuk tetap menjaga protokol kesehatan, masing-masing desa juga diberikan alat pengukur suhu (thermogun), pemberian masker kain, hand sanitizer dan khusus desa Aikdewa diberikan bak penampung (Tandon) air tempat cuci tangan.

Pada saat proses distribusi bantuan langsung tim pengabdian masyarakat memberikan bantuan paket bahan makanan berupa beras sebanyak $5 \mathrm{~kg}$, minyak goreng 1 liter, gula pasir $1 \mathrm{~kg}$, mie instan 20 pcs dan vitamin C. Kegiatan pemberian bantuan makanan pokok ini sangat bermanfaat bagi masyarakat kurang mampu dan dapat membantu meringankan beban mereka, juga bermanfaat bagi tim pelaksana pengabdian dalam upaya meningkatkan rasa kebersamaan dan sosial yang tinggi.

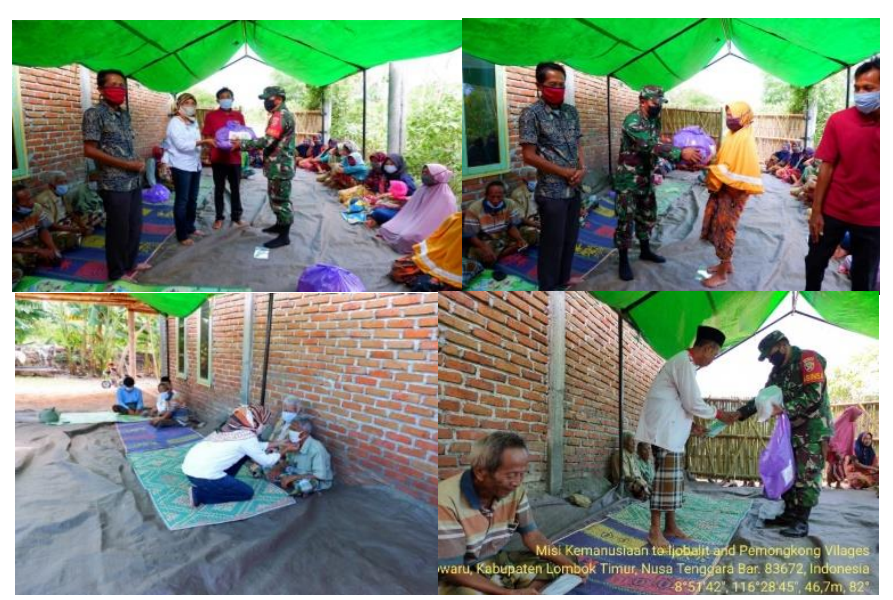

Gambar 4. Kegiatan Distribusi Bantuan Langsung

Paket Bahan Makanan di Desa Pemongkong 


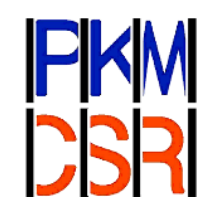

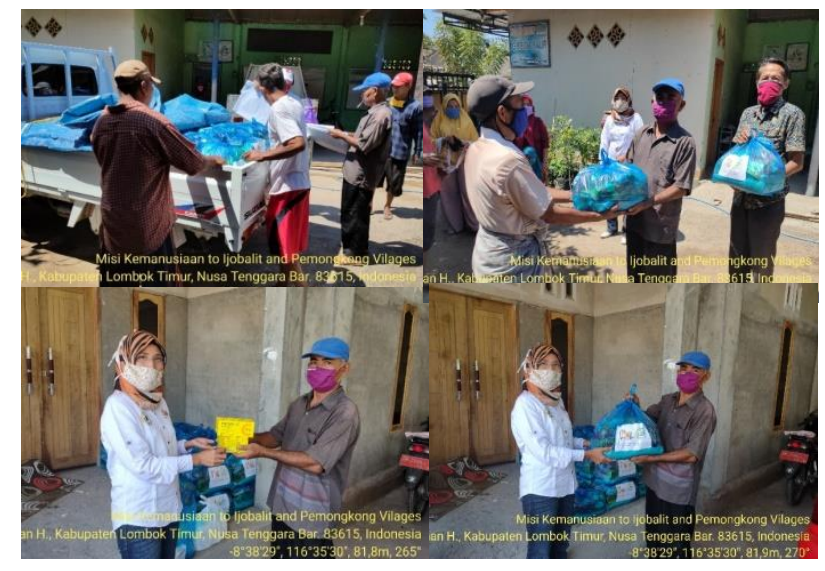

Gambar 5. Kegiatan Distribusi Bantuan Langsung

Paket Bahan Makanan di Desa Ijobalit

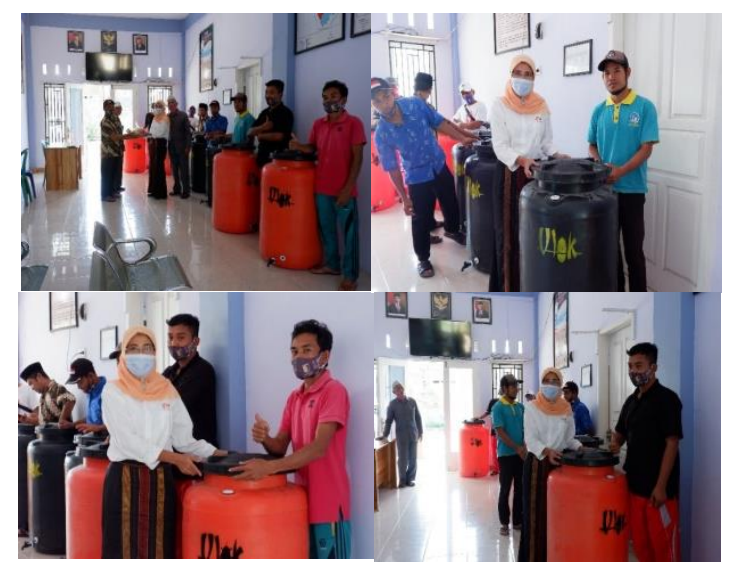

Gambar 6. Kegiatan Distribusi Bantuan Langsung

Paket Bahan Makanan di Desa Aikdewa

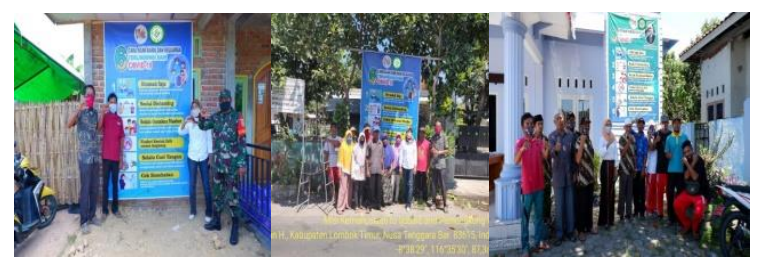

Gambar 7. Pemasangan Poster Covid-19 Di Desa Pemongkong,

Desa Ijobalit dan Desa Aikdewa

\section{KESIMPULAN}

Pendampingan dan pemberdayaan pada masyarakat dalam membantu masyarakat kurang mampu yang dilaksanakan oleh penulis bekerjasama dengan Vlok Foundation
Holland di Desa Pemongkong, Desa Ijobalit dan Desa Aikdewa Kabupaten Lombok Timur bertujuan untuk memberikan sumbangsih dalam membantu meringankan kebutuhan masyarakat dan memotivasi masyarakat untuk menerapkan protokol kesehatan dengan selalu mencuci tangan, menjaga jarak dan menggunakan masker jika beraktivitas ditempat-tempat umum agar terhindar dari penularan Covid-19, serta meningkatkan imunitas tubuh dengan mengkonsumsi makanan yang sehat dan bergizi.

\section{UCAPAN TERIMA KASIH}

Melalui kesempatan ini, penulis menyampaikan terima kasih dan penghargaan yang setinggi-tingginya kepada Vlok Foundation Holland atas bantuan biaya pada masyarakat kurang mampu di desa Pemongkong, desa Ijobalit dan desa Aikdewa kabupaten Lombok Timur, juga ucapan terima kasih dan penghargaan yang setinggi-tingginya kepada Bupati Lombok Timur dan seluruh masyarakat Kabupaten Lombok Timur yang telah berperan aktif dalam mensukseskan kegiatan ini. Ucapan terima kasih juga kami sampaikan kepada Lembaga Pengabdian dan Penelitian Pada Masyarakat (LPPM) Universitas Islam AlAzhar Mataram atas bantuan dan dukungannya sehingga pengabdian masyarakat dapat diselesaikan dengan baik.

\section{DAFTAR PUSTAKA}

Anonim, (2018), Dinas Kesehatan, Kabupaten Lombok Timur

Badan Pusat Statistik Kabupaten Lombok Timur, (2021), Kabupaten Lombok Timur Dalam Angka, ISSN-02156059, Katalog 1102001.5203. BPS Kabupaten Lombok Timur.

Haris, A. (2014) "Memahami Pendekatan Pemberdayaan Masyarakat", Jupiter, XIII(2).

Menteri Dalam Negeri (Mendagri). (2020), Surat Edaran Menteri Dalam Negeri (Mendagri) Nomor : 440/2436/SJ/2020 Tentang 
Pencegahan Covid-19 di SMERU, PROSPERA, UNDP, UNICEF, lingkungan Pemerintah Daerah. (2021) "Dampak Sosial Ekonomi COVID-19 terhadap Rumah Rizki Fillaili, Ana Rosidha Tamyis, (2020), Me Komunikasi Risiko yang Efektif Pengembangan Penghidupan \& Tangga dan Rekomendasi Kebijakan Strategis untuk Indonesia", Dalam Publikasi Indonesia, Briefs, December, 2020, Final Organisasi Lain Maret, 2021 